\title{
Hepatitis B Surface Antigen Serum Level Is Correlated with Fibrosis Severity in Treatment-Naïve, Chronic Hepatitis B Patients in Côte d'Ivoire (West Africa)?
}

\author{
Mamert Fulgence Yao Bathaix ${ }^{1 *}$, Dramane Soro², Aboubacar Demba Bangoura1, \\ Adjéka Stanislas Doffou ${ }^{1}$, Siaka Koné2, Ya Henriette Kissy ${ }^{1}$, Dimitri Hartrydt Kouamé1, \\ Aoudi Ousmane Dé1, Mahassadi Kouamé Alassane1, Attia Koffi Alain1, \\ Aya Thérèse N'Dri Yoman' ${ }^{1}$ \\ ${ }^{1}$ Department of Hepatology and Gastroenterology of the Centre Hospitalier Universitaire de Yopougon \\ (CHU-Y), Abidjan, Côte d'Ivoire \\ ${ }^{2}$ Department of Hepatology and Gastroenterology of the Centre Hospitalier Universitaire de Cocody (CHU-C), \\ Abidjan, Côte d'Ivoire \\ Email: ${ }^{*}$ bathaixful@yahoo.fr
}

Received 21 October 2015; accepted 22 November 2015; published 25 November 2015

Copyright (C) 2015 by authors and Scientific Research Publishing Inc.

This work is licensed under the Creative Commons Attribution International License (CC BY). http://creativecommons.org/licenses/by/4.0/

(c) (i) Open Access

\begin{abstract}
HBsAg serum level (quantification) may be useful for managing hepatitis B virus (HBV) infection patients. However few studies especially in Africa have evaluated the association between HBsAg serum level and liver fibrosis severity. The objective of this study was to estimate the correlation between HBsAg serum level and liver fibrosis severity with treatment naïve chronic hepatitis B patients in Côte d'Ivoire. Methodology: It is a prospective study covering from February 1st, 2014 to April 30st, 2015 at Centre Hospitalier et Universitaire de Yopougon and a private medical office in Abidjan, Côte d'Ivoire. Inclusion criteria for patients were: HBsAg positive, known HBeAg status, serum HBsAg levels, serum HBV DNA levels, complex serum markers and absence of HCV, HDV, or HIV co-infection, drinking more than $30 \mathrm{~g}$ /day for men and $20 \mathrm{~g}$ /day in women over 10 years, metabolic disease and/or hepatic overload. Pearson's Chi-square test (r2), Anova, Spearman, T-Student, Pearson's ( $r$ ) correlations and Mann Withney's Test were carried out as appropriate. A p value $<0.05$ was taken as significant. Results: We recruited, 105 patients $(77$ men) of whom the medium age was $39.01 \pm 9.72$ years. Predominant hepatitis B viral genotype was E $(93 \%)$. Less than $10 \%$ patients had an inactive HBV in HBeAg-negative. Patients had an average high HBsAg serum level (mean 12111.2 $\pm 10617.4 \mathrm{IU} / \mathrm{ml}$ ) as well as the one viral load (mean $4.4 \mathrm{e} 7 \pm 7.5 \mathrm{e} 7$ ). Serum ALAT levels averaged at the upper limit of normal value. The average liver fibrosis score was $0.34 \pm 0.22$

*Corresponding author.
\end{abstract}

How to cite this paper: Yao Bathaix, M.F., et al. (2015) Hepatitis B Surface Antigen Serum Level Is Correlated with Fibrosis Severity in Treatment-Naïve, Chronic Hepatitis B Patients in Côte d'Ivoire (West Africa)? Open Journal of Gastroenterology, 5, 164-172. http://dx.doi.org/10.4236/ojgas.2015.511026 
and the degree of viral activity was $0.19 \pm 0.20$. Half of our patients had no fibrosis $(35.24 \%)$ or had mild fibrosis $(20.95 \%)$. No significant association was observed between HBsAg serum level and patient age $(p=0.3994)$, genre $(p=0.8075)$ or serum ALT levels $(p=0,0787)$. In multivariate analysis, there's a significant correlation $(r=0.239, p=0.014)$ between HBV DNA levels and HBsAg serum level. There's a significant correlation $(r=0.923, p<0.0001)$ between HBsAg serum level and the dosage of alpha-fetoprotein. HBsAg serum level was not associated with the fibrosis stage ( $p=0.281$ ). HBsAg levels average with patients without fibrosis or carry a slight fibrosis (F0, F1) was higher than patients with moderate to severe fibrosis (F2, F3, F4): $13679.2 \mathrm{UI} / \mathrm{ml} \pm 1956.48$ versus $10610.52 \mathrm{UI} / \mathrm{ml} \pm 8998.99(\mathrm{p}=0.29)$. There's a negative correlation between HBsAg level and the liver fibrosis score was negative $(r=-0.069, p=0.48)$. No significant association between HBsAg level and the liver fibrosis patients that were normal $(p=0.7965)$ or elevated $(p=0.5845)$. HBV DNA level was significantly associated with fibrosis score $(r=0.30, p=0.0018)$. Conclusion: This study shows that there's a negative correlation between HBsAg serum level and liver fibrosis severity treatment naïve with African chronic hepatitis B viral HBeAg-negative patients.

\section{Keywords}

Hepatitis B Surface Antigen Serum Level, Liver Fibrosis, Chronic Hepatitis B Viral, Africa

\section{Introduction}

Viral B cirrhosis by its complications is the leading cause of death for chronic liver diseases in Côte d'Ivoire. This cirrhosis occurs at a final stage of liver fibrosis, in our context due to hepatitis B virus (HBV) in the majority of cases [1] [2]. Fibrosis evaluation can ask therapeutic indications and improve the care of patients HBV to reduce morbidity and mortality from cirrhosis. Several methods are used to assess liver fibrosis severity: transient elastography [3], complex serum markers [4] [5] and histopathological evaluation after performing a liver biopsy [6]. This last decade has seen the birth of a new marker in the therapeutic approach of chronic HBV patients: HBsAg serum level [7].

Hepatitis B surface antigen (HBsAg), which forms the protein envelope of the virus, is generally regarded as a diagnostic for HBV infection [8]. Serum HBsAg levels have been demonstrated to be clinically useful to identify the stage of disease [9] [10], to distinguish true inactive carriers from patients with hepatitis B e antigen-negative (HBeAg-negative) disease [11] [12], and to predict response to interferon therapy [13] [14]. Recent researches have also demonstrated that HBsAg levels are associated with the risk of progression to hepatocellular carcinoma, especially with low Hepatitis B Viral deoxyribonucleic acid (HBV DNA) levels patients [15] [16]. Little is currently known about the association between HBsAg or HBV DNA levels and the severity of liver disease at any specific time point. In contrast to HBV DNA [17] [18], only one published study has investigated the potential correlation between HBsAg levels and the stage of fibrosis [19].

Few studies have evaluated in Sub-Saharan Africa interest HBsAg serum level with the treatment of chronic hepatitis B viral patients. We conducted this study in order to evaluate correlation between HBsAg serum level and liver fibrosis severity.

\section{Methodology}

\subsection{Study Oversight}

Retrospective, transversal and analytical study which took place over 14 months. From February 2014 through April 2015, we consecutively enrolled treatment-naïve chronic hepatitis B (CHB) patients who were admitted in the Centre Hospitalier et Universitaire de Yopougon and a private medical office in Abidjan, Côte d'Ivoire. No commercial support was involved in the study. All the authors vouch for the integrity and the accuracy of the analysis and for the fidelity of the study.

\subsection{Selection of Patients}

Selected, consecutive, treatment-naïve CHB patients were assessed at the Centre Hospitalier et Universitaire de 
Yopougon and a private medical office in Abidjan, Côte d'Ivoire, between 2014 February and 2015 April. Patients inclusion criteria were: the HBsAg positive, the HBeAg status, the serum HBsAg levels, the complex serum markers and absence of Hepatitis C Virus (HCV), Hepatitis D Virus (HDV), or Human Immunodeficiency Virus (HIV) co-infection, drinking more than $30 \mathrm{~g} /$ day for men and $20 \mathrm{~g} /$ day in women over 10 years, metabolic disease and/or hepatic overload.

\subsection{Studied Variables}

The anthropometric variables were the age, the gender. The clinic variables were the discovery circumstances. The biological variables studied were the serum HBsAg levels, the viral markers, the HBV genotype, the alpha fetoprotein, the serum HBV DNA levels, the alanine aminotransferase (ALT) levels, the aspartate aminotransferase (ASAT) levels, the haptoglobin, the alpha 1 apolipoprotein, the macroglobulin alpha 2, the total bilirubin, the gamma-glutamyl transferase, the prothrombin rate, the triglycerid, the creatinine and the platelets. The score and liver fibrosis stage evaluated by biochemical markers of liver activity and fibrosis (Actitest ${ }^{\circledR}$-Fibrotest ${ }^{\circledR}$ ) were also been studied. These data were collected from the files of consulted patients on pre-established survey forms.

Measurement of HBsAg levels and HBV DNA levels: HBsAg levels in patient serum samples were quantified using the Cobas electro-chemiluminescence immunoassay (Roche Diagnostics) and expressed as log IU/ml. Serum HBV DNA levels were determined using the TaqMan_assay (Roche Diagnostics) polymerase chain reaction expressed as $\log \mathrm{IU} / \mathrm{ml}$.

\subsection{Statistical Analysis}

Continuous variables were expressed as the mean \pm standard deviation (range) for normal distributions or the median (interquartile range, IQR) for abnormal distributions. Pearson's Chi-square test, Analysis of variance, Spearman, T-Student and Pearson's (r) correlations were carried out as appropriate. Averages comparison was made with the test of Mann Withney. All tests for significance and resulting $\mathrm{p}$ values were two-sided, with a level of significance of 0.05 . The statistical software used for this analysis was Stata 13.1.

\subsection{Ethical Approval}

The analysis was conducted on anonymized data, collected aspart of routine patient care. No additional investigations were per-formed. Therefore, no prior informed consent from the patients was required.

\section{Results}

Over the period of our study we recruited 105 patients (77 men) with an average of $39.01 \pm 9.72$ years. The main hepatitis B viral genotype was E (93\%). Less than 10\% of chronic hepatitis B patients had HBeAg-negative inactive. Patients had an elevated average serum HBsAg levels (mean $12111.2 \pm 10617.4 \mathrm{IU} / \mathrm{ml}$ ) as well as the average serum HBV DNA levels (mean $4.4 \mathrm{e} 7 \pm 7.5 \mathrm{e} 7$ ). Transaminases rate averaged at the upper limit of normal value. The average liver fibrosis score was $0.34 \pm 0.22$. Half of our patients had no fibrosis (35.24\%) or had mild fibrosis (20.95\%). Patient's characteristics are shown in Table 1.

No significant association was observed between serum HBsAg levels and patient age, genre or serum ALT levels (Table 2).

In multivariate analysis, there's a significant correlation $(\mathrm{R}=0.239, \mathrm{p}=0.014)$ between HBV DNA levels and HBsAg serum levels (Figure 1). There was a significant correlation $(\mathrm{R}=0.92, \mathrm{p}<0.0001$ ) between HBsAg levels and assay of alpha feto-protein (Figure 2).

Serum HBsAg levels was not associated to the stage fibrosis $(p=0.281)$ (Figure 3). The HBsAg levels average with patients without fibrosis or carry a slight fibrosis (F0, F1) was higher than that of patients with moderate to severe fibrosis (F2, F3, F4): $13679.2 \mathrm{IU} / \mathrm{ml} \pm 1956.48$ versus $10610.5 \mathrm{IU} / \mathrm{ml} \pm 8998.99(\mathrm{p}=0.29)$. There was a negative correlation $(r=-0.069, p=0.48)$ between HBsAg levels and the liver fibrosis score (Figure 4). We noted a lack of significant association between HBsAg levels and fibrosis with patients with normal ALT ( $p$ $=0.7965)$ or high $(\mathrm{p}=0.5845)$. HBV DNA levels was significantly associated with fibrosis score $(\mathrm{r}=0.30, \mathrm{p}=$ 0.0018) (Figure 5). 
Table 1. Demographics, clinical and biological characteristics of patients included in the study.

\begin{tabular}{|c|c|}
\hline Number of patients & (105) \\
\hline \multicolumn{2}{|l|}{ Demography } \\
\hline -Age & 15 - 69 years ( $39.01 \pm 9.72$ years; median 38 years) \\
\hline -Sex ratio $(\mathrm{M} / \mathrm{F})$ & 2.74 \\
\hline Discovery circumstances & Screening (38.10\%), fortuitous (56.19\%), symptomatic (5.71\%) \\
\hline \multicolumn{2}{|l|}{ Biological variables } \\
\hline -HBV genotype & E (98) NP (7) \\
\hline -HBsAg quantification (N < $0.05 \mathrm{IU} / \mathrm{ml})$ & 1.69 - 6199 UI/ml (mean $12111.2 \pm$ 10617.4; median 98.41) \\
\hline -HBV HBeAg-négatif & Active (96), inactive (9) \\
\hline -HBV DNA levels (N < 20 IU/ml) & 154 - 1.7 (mean 4.4 e7 \pm 7.5 e7; median 9685.5) \\
\hline -Transaminases ALAT (N < 35 IU/ml) & 9 - 422 UI/ml (mean $38.62 \pm$ 51.12; median 26) \\
\hline ASAT (N < $40 \mathrm{IU} / \mathrm{ml})$ & 10 - 313 UI/ml (mean $38.67 \pm 41.88$; median 27) \\
\hline -Prothrombine rate ( $\mathrm{N} \geq 70 \%)$ & $56 \%$ - 100\% (mean $83.25 \pm 8.13$; median 83) \\
\hline -Triglycerid levels $(\mathrm{N}<2$ gr/l) & 0.12 - 2.17 mg/l (mean $0.74 \pm 0.35$; median 0.70 ) \\
\hline -Creatinine ( < 15 mg/l)) & 6 - 16.3 mg/l (mean $9.47 \pm 1.72$; median 9.1) \\
\hline -Platelets (N = 150 - 450 GIGA/L) & 24 - 389 GIGA/L (mean $186 \pm$ 54; median 195) \\
\hline -Alpha Feto-protein (N < $8.5 \mathrm{IU} / \mathrm{ml})$ & 0.5 - 50.14 (mean $2.84 \pm 5.35$; median 1.51) \\
\hline \multicolumn{2}{|l|}{ Complex serum markers parameters } \\
\hline -Total bilirubin $(\mathrm{N}<12.3 \mathrm{mg} / \mathrm{L})$ & 2 - 54 mg/L (mean $11.63 \pm$ 7.71; median 9.8) \\
\hline -Gammaglutamyl transferase (N < $40 \mathrm{IU} / \mathrm{ml})$ & 11 - 183 UI/L (mean 45.48 × 34.38; median 34) \\
\hline -Haptoglobin levels ( $\mathrm{N}=0.58$ - $1.55 \mathrm{~g} / \mathrm{L})$ & $0.1-1.87 \mathrm{~g} / \mathrm{L}$ (mean $0.81 \pm 0.5$; median 0.83 ) \\
\hline -Apolipoprotein (N = 1.08 - 2.25 g/L) & $0.32-2.07 \mathrm{~g} / \mathrm{L}$ (mean $1.30 \pm 0.28$; median 1.31 ) \\
\hline -Macroglobulin $\alpha 2(\mathrm{~N}=1.75$ - $4.20 \mathrm{~g} / \mathrm{L})$ & 1.02 - 5.25 g/L (mean $2.14 \pm 0.71$; median 1.97 ) \\
\hline -Fibrosis stage (F0-F4) & F0 (37), F1 (22), F2 (28), F3 (9), F4 (9). \\
\hline -Fibrosis score (0.00 - 1.00) & 0.03 - 0.96 (mean $0.34 \pm 0.22$; median 0.29 ) \\
\hline -Activity score (0.00 - 1.00) & $0.01-0.98$ (mean $0.19 \pm 0.20 ;$ median 0.13 ) \\
\hline
\end{tabular}

Table 2. Serum HBsAg levels associated factors in univariate analysis.

\begin{tabular}{ll}
\hline Studied variables & P \\
\hline Age (median) 38 years & 0.3994 \\
Gender: male (77) & 0.8075 \\
Transaminases & 0.0787 \\
\hline
\end{tabular}

\section{Discussion}

Côte d'Ivoire is a highly endemic area of viral infection B with an estimated HBsAg prevalence of $10 \%$ [1].

According to the inclusion criteria, our study population was 105 patients. This number can be explained firstly that HBsAg levels determination is expensive and other shares that review is not yet systematically requested by physicians supporting hepatitis chronic viral B patients. Martinot-Peignoux [5] had a larger cohort of patients in his study but extended to all HBV genotypes and also it came from a study that had benefited from funding. In sub Saharan Africa, few studies have investigated the correlation between serum HbsAg levels and liver diseases. 


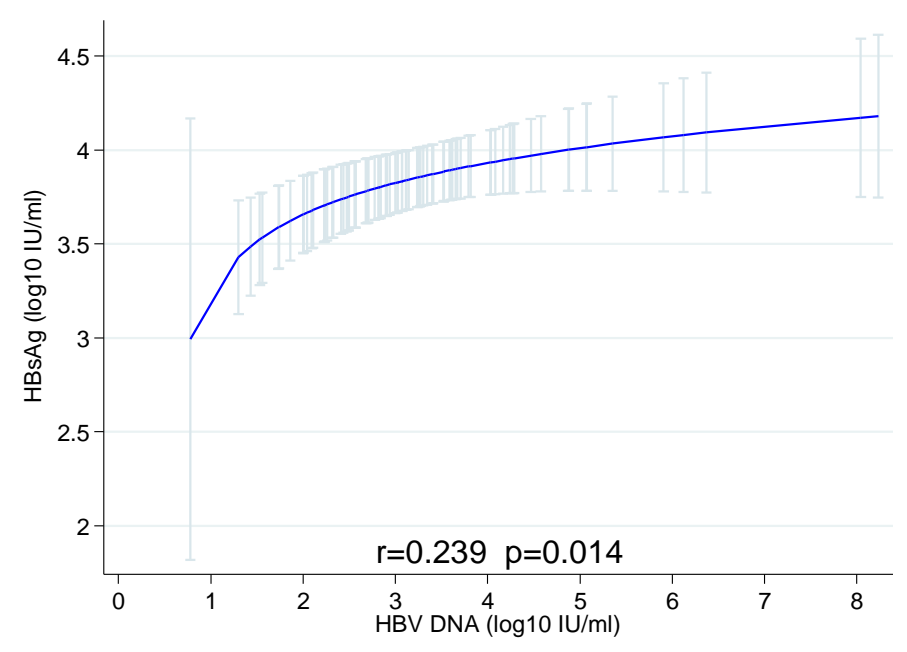

Figure 1. Correlation between HBsAg serum levels and HBV DNA levels. Method: Fractional polynomial w/CI fit plots.

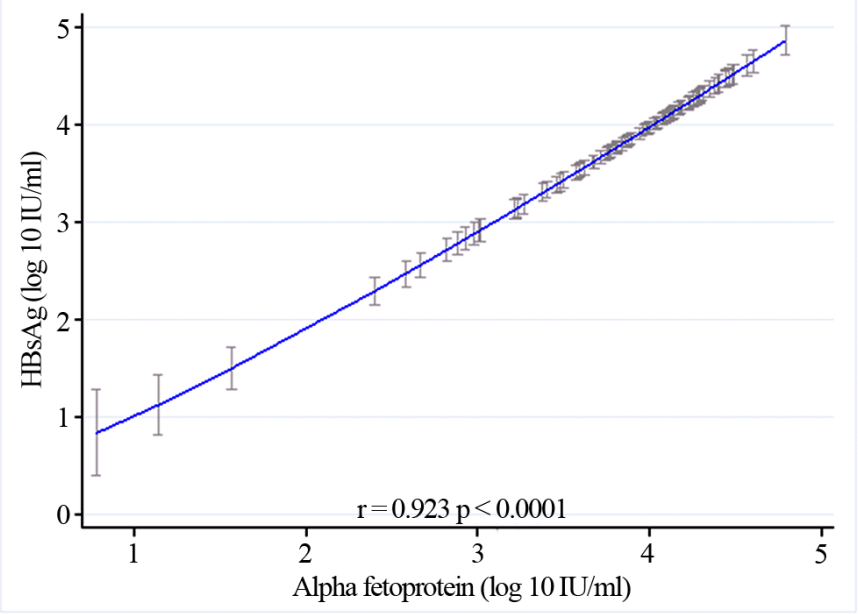

Figure 2. Correlation between HBsAg serum levels and alpha fetoprotein.
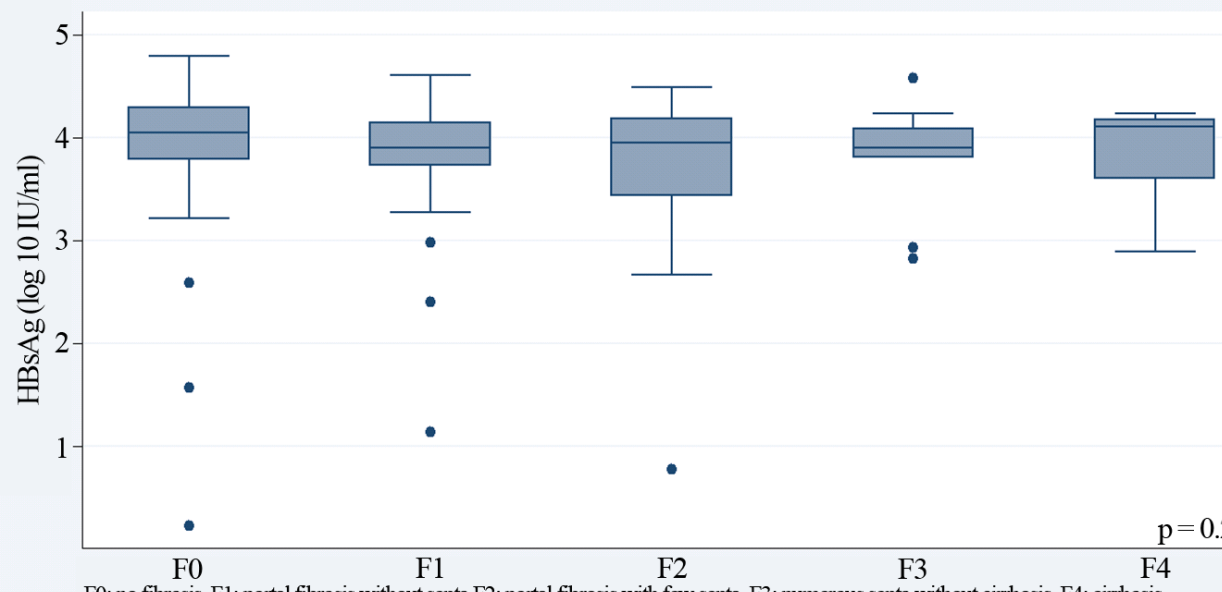

F0: no fibrosis. F1: portal fibrosis without septa F2: portal fibrosis with few septa. F3: numerous septa without cirrhosis. F4: cirrhosis

Figure 3. Distribution HBsAg levels patients by liver fibrosis stage. 


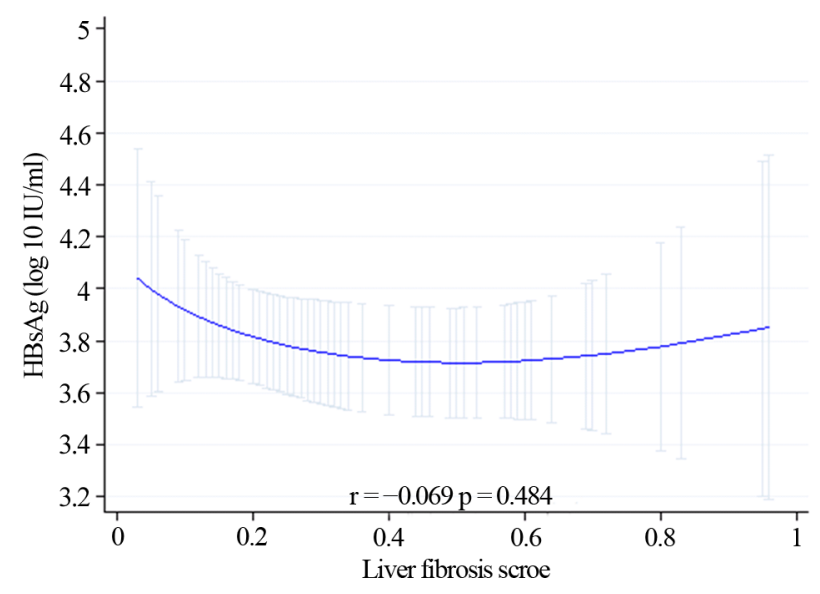

Figure 4. Correlation between HBsAg serum level and liver fibrosis score.

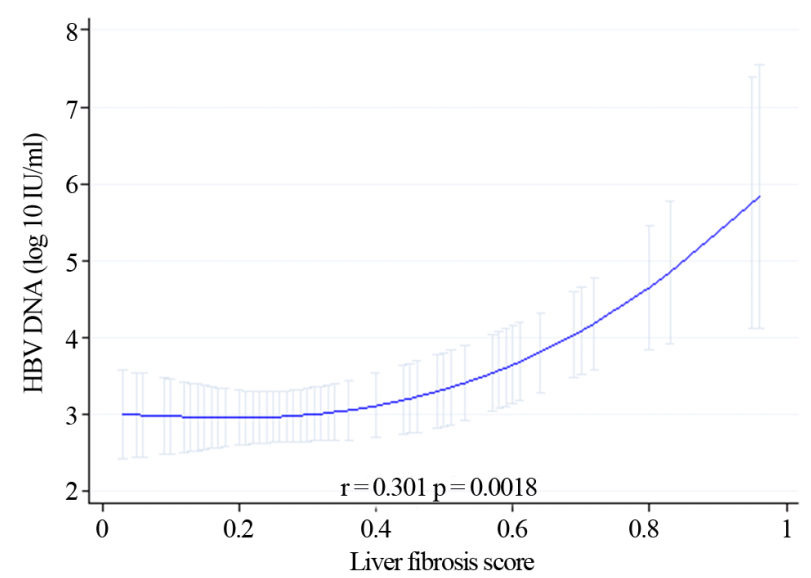

Figure 5. Correlation between HBV DNA level and liver fibrosis score.

The sex ratio in our study was 2.75 men per 1 woman. This male predominance in viral infection B is consistent with literature data [7] [20] [21]. The average age of patients was 39.17 years (extremes: 15 years - 69 years). This data is the same with those Tan [7] found a mean age of $37 \pm 12$ years and Sombié [21] had an average age of 32 years, ranging from 17 to 67 ans. Multiple use of contaminating materials and sexual risk behaviors were the most found risk factors in the patients' story. Kodjoh [22] made the same finding in his study.

The hepatitis mode of revelation was made fortuitous (56.19\%) or during a screening (38.10\%). Creach [23] noted in his series $39.4 \%$ of cases discovered during screening against 30.3\% during a blood donation. Sombié [21] also showed that fortuitous discovery during blood donation (53.36\%), health record (34.11\%) of HBV was the most revelation common way.

The majority of chronic hepatitis viral B patients (93.33\%) had genotype E. The literature also reports a high frequency of genotype E in Sub-Saharan Africa [24] [25]. Patients' proportion for which genotype was not specified is the lack of financial means and inadequate technical facilities in our work environment. All patients $(100 \%)$ in the study were carriers of chronic viral hepatitis B HBeAg-negative. Creach and all [23] identified in their series $69.7 \%$ patients HBeAg-negative and $88.68 \%$ of subjects HBeAg-negative in Sombié's serie [21].

Martinot-Peignoux [5] and Tan [7] have found chronic hepatitis viral B HBsAg-negative patients in respective proportions of $75.12 \%$ and $27.46 \%$. The high rate of carriers of HBeAg-positive in Tan's study is related to the fact that he made a study on serum HBsAg levels in the natural history HBV infection. He had a large proportion of immunotolerant treatment naïve patients.

Less than $10 \%$ of patients in our study were true inactive carriers in a study according to criteria studies Bru- 
netto [26] and Jaroszewicz [9]. Tan and all [7] have rather a higher rate (32\%) of inactive carrying in his study. Tan's study [7] defined inactive carriers without including HBsAg levels which certainly has overestimated the inactive carrier's number unlike ours. It took into account two parameters: alanine aminotransferase (ALT) and HVB DNA levels. It is based on persistence of the normal ALT rate $(<35 \mathrm{IU} / \mathrm{ml})$ and HBV viral load $<2000$ $\mathrm{IU} / \mathrm{ml}$ dosed every three or four months a minimum monitoring 1 year. However, this subgroup of patients, very inactive carriers has a lower risk of developing hepatocellular carcinoma in the course of the diseases [16].

Patients have the mean serum HBsAg levels and HBV DNA levels greater than those observed in HBeAgnegative CHB in Western and Asian series [5] [7].

It is worth noting that no correlation was observed between HBsAg and HBV DNA levels or age for HBeAgnegative CHB cases. HBeAg-negative CHB may follow HBe seroconversion during the immune reactive phase or may develop after years or decades of the inactive carrier state. Furthermore, HBeAg-negative CHB patients have a high risk of progression to advanced hepatic fibrosis, cirrhosis and subsequent complications such as decompensated cirrhosis and hepatocellular carcinoma [27].

However, among HBeAg-negative patients with low viral loads, the risk of hepatocellular carcinoma is determined by HBsAg levels, ALT and age, but not HBV DNA [16]. A decline of serum HBsAg levels represents a reduction in the translation of mRNAs produced from transcriptionally active cccDNA or integrated sequences [26].

No significant correlation was observed between serum HBsAg or HBV DNA levels and patient age, sex, or serum ALT level (data not shown) [5].

In our study, there's significant correlation $(r=0.239$, $p=0.014)$ between HBsAg levels and HBV DNA levels. A cross-sectional study demonstrated there was no significant correlation between HBsAg levels and HBV DNA levels for HBeAg negative patients [28].

Martinot-Peignoux et al. [ref] found significant correlation $(r=0.438, p<0.0001)$ between HBsAg levels and HBV DNA levels to HBsAg-positive patients but not among HBsAg-negative. The same was found in the literature [7] [10] [29].

Our study shows a significant correlation $(\mathrm{p}<0.0001)$ between serum HBsAg levels and especially alpha fetoprotein for levels of HBsAg levels $>1000 \mathrm{IU} / \mathrm{ml}$. This could presage the risk of developing hepatocellular carcinoma with these patients [16].

The average HBsAg levels patients without fibrosis or carry slight fibrosis (F0, F1) was elevated than that patients with moderate to severe fibrosis (F2, F3, F4) with no statistically significant difference $(p=0.29)$. There was no significant difference in serum HBsAg levels of HBeAg-negative patients with moderate to severe fibrosis compared with those with no or mild fibrosis. However, HBV DNA levels were significantly higher in HBeAg-negative patients with moderate to severe disease [5].

In our study, there was a negative correlation between HBsAg levels and fibrosis degree $(r=-0.069, p=$ 0.484) with patients. Martinot-Peignoux [5] also found that there is no positive correlation between HBsAg levels and hepatic fibrosis in HBV to HBeAg-negative.

The decline in HBsAg levels with increasing severity of fibrosis may be due to the retention of HBsAg within cells rather than secretion, or a diminishing ability of the host to support viral replication. We observed an increasing HBV DNA levels associated with severity of fibrosis in HBeAg-negative patients, which has also been previously described [18] [30]. This is presumably due to the increasing viral load exacerbating the disease process, possibly due to a loss or lessening in the ability of the host to suppress viral replication. The authors observed a general reduction in HBsAg levels with an increasing in age [31].

Perinatally acquired HBV is the main model of chronic HBV infection in China; hence the age of patients indicates the duration of infection for the majority of the chronic HBV infection and is considered an important factor associated with the progression of HBV-related diseases. The negative correlation between HBsAg levels and age, and the decline in HBsAg levels associated with the progressive phases of the natural history of HBV infection, demonstrate that HBs Ag levels are reflective of antivirus immunity and the duration of HBV infection, particularly for HBeAg-positive patients [31].

Study limitations are the weakness of our sample expensive option because of high cost biological tests to perform particularly complex serum markers and hepatic viral markers. Furthermore, the serum samples have not always been taken on the same day in all cases. Clinicians must interpret biochemical markers of liver activity and fibrosis results with caution in patients with a significant elevation of ALT, and/or GGT and/or alpha2-macroglobulin which could overestimate hepatic injury. 


\section{Conclusion}

The results of this study show that there is a negative correlation between HbsAg levels and liver fibrosis severity with African chronic viral hepatitis B HBeAg-negative patients.

\section{References}

[1] Yao Bathaix, M.F., Attia, K.A., Bagny, A., Bangoura, D.A., Mahassadi, K.A., Kouamé, D.H., Kissi-Anzouan, O., Diallo, K. and Ndri-Yoman, A.T. (2015) Niveau de connaisances des sages-femmes sur la prévention de la transmission mère-enfant du virus de l'hépatite B à Abidjan (Côte d'Ivoire). Journal Africain d'Hépato-Gastroentérologie, 9, 22-25.

[2] Attia, K.A., N’dri Yoman, A.T., Talla, P., Bathaix, Y., Mahassadi, A., et al. (2003) Facteurs prédictifs des signes endoscopiques d'hypertension portale sévère chez le cirrhotique en milieu Africain: A propos de 131 cas. Médecine d'Afrique Noire, 50, 109-114.

[3] Liang, L.-B., Zhu, X., Yan, L.-B., Du, L.-Y., Liu, C., Chen, L.-Y., et al. (2015) Serum Hepatitis B Surface Antigen Titer and Transient Elastography in Screening for Insignificant Fibrosis in HBeAg-Positive Chronic Hepatitis B Patients. Therapeutics and Clinical Risk Management, 11, 229-235.

[4] Anastasiou, J., Alisa, A., Virtue, S., Portmann, B., Murray-Lyon, I. and Williams, R. (2010) Non Invasive Markers of Fibrosis and Inflammation in Clinical Practice: Prospective Comparison with Liver Biopsy. European Journal of Gastroenterology \& Hepatology, 22, 474-478. http://dx.doi.org/10.1097/MEG.0b013e328332dd0a

[5] Martinot-Peignoux, M., Carvalho-Filho, R., Lapalus, M., Netto-Cardoso, A.C.F., et al. (2013) Hepatitis B Surface Antigen Serum Level Is Associated with Fibrosis Severity in Treatment-Naïve, e Antigen-Positive Patients. Journal of Hepatology, 58, 1089-1095. http://dx.doi.org/10.1016/j.jhep.2013.01.028

[6] Wang, H., Yan, R., Zhou, Y., Wang, M.S., Ruo, G.Q. and Cheng, M.J. (2014) Comparison of Hepatitis B Surface Antigen and e Antigen in Predicting Liver Histology in Hepatitis B e Antigen-Positive Chronic Hepatitis B Patients. Hepatology International, 8, 216-223. http://dx.doi.org/10.1007/s12072-013-9502-8

[7] Tan, Z., Lia, M., Kuang, X., Tang, Y., Fan, Y., Deng, G., Wang, Y. and He, D. (2014) Clinical Implications of Hepatitis B Surface Antigen Quantitation in Thenatural History of Chronic Hepatitis B Virus Infection. Journal of Clinical Virology, 59, 228-234. http://dx.doi.org/10.1016/j.jcv.2014.01.013

[8] Liaw, Y.-F. (2009) Hepatitis B Infection. Lancet, 373, 582-592. http://dx.doi.org/10.1016/S0140-6736(09)60207-5

[9] Jaroszewicz, J., Calle Serrano, B., Wursthorn, K., Deterding, K., Schlue, J., Raupach, R., et al. (2010) Hepatitis B Surface Antigen (HBsAg) Levels in the Natural History of Hepatitis B Virus (HBV)-Infection: A European Perspective. Journal of Hepatology, 52, 514-522. http://dx.doi.org/10.1016/j.jhep.2010.01.014

[10] Nguyen, T., Thompson, A.J., Bowden, S., Croagh, C., Bell, S., Desmond, P.V., et al. (2010) Hepatitis B Surface Antigen Levels during the Natural History of Chronic Hepatitis B: A Perspective on Asia. Journal of Hepatology, 52, 508-513. http://dx.doi.org/10.1016/j.jhep.2010.01.007

[11] Brunetto, M.R., Oliveri, F., Colombatto, P., Moriconi, F., Ciccorossi, P., Coco, B., et al. (2010) Hepatitis B Surface Antigen Serum Levels Help to Distinguish Active from Inactive Hepatitis B Virus Genotype D Carriers. Gastroenterology, 139, 483-490. http://dx.doi.org/10.1053/j.gastro.2010.04.052

[12] Liaw, Y.-F. (2011) Clinical Utility of Hepatitis B Surface Antigen Quantification in Patients with Chronic Hepatitis B: A Review. Hepatology, 54, 1-9. http://dx.doi.org/10.1002/hep.24473

[13] Brunetto, M.R., Moriconi, F., Bonino, F., Lau, G.K., Farci, P., Yurdaydin, C., et al. (2009) Hepatitis B Virus Surface Antigen Levels: A Guide to Sustained Response to Peginterferon Alfa-2a in HBeAg-Negative Chronic Hepatitis B. Hepatology, 49, 1141-1150. http://dx.doi.org/10.1002/hep.22760

[14] Moucari, R., Mackiewicz, V., Lada, O., Ripault, M.P., Castelnau, C., Martinot-Peignoux, M., et al. (2009) Early Serum HBsAg Drop: A Strong Predictor of Sustained Virological Response to Pegylated Interferon Alfa-2a in HBeAg-Negative Patients. Hepatology, 49, 1151-1157. http://dx.doi.org/10.1002/hep.22744

[15] Chan, H.L. (2012) Identifying Hepatitis B Carriers at Low Risk for Hepatocellular Carcinoma. Gastroenterology, 142, 1057-1060. http://dx.doi.org/10.1053/j.gastro.2012.03.013

[16] Tseng, T.C., Liu, C.J., Yang, H.C., Su, T.H., Wang, C.C., Chen, C.L., et al. (2012) High Levels of Hepatitis B Surface Antigen Increase Risk of Hepatocellular Carcinoma in Patients with Low HBV Load. Gastroenterology, 142, 11401149. http://dx.doi.org/10.1053/j.gastro.2012.02.007

[17] Chan, H.L., Tse, C.H., Mo, F., Koh, J., Wong, V.W., Wong, G.L., et al. (2010) High Viral Load and Hepatitis B Virus Subgenotype C Are Associated with Increased Risk of Hepatocellular Carcinoma. Journal of Clinical Oncology, 26, 177-182. http://dx.doi.org/10.1200/JCO.2007.13.2043

[18] Chen, C.J., Yang, H.I., Su, J., Jen, C.L., You, S.L., Lu, S.N., et al. (2006) Risk of Hepatocellular Carcinoma across a 
Biological Gradient of Serum Hepatitis B Virus DVA Level. JAMA, 295, 65-73. http://dx.doi.org/10.1001/jama.295.1.65

[19] Seto, W.K., Wong, D.K., Fung, J., Ip, P.P., Yuen, J.C., Hung, I.F., et al. (2012) High Hepatitis B Surface Antigen Levels Predict Insignificant Fibrosis in Hepatitis B e Antigen Positive Chronic Hepatitis B. PLoS ONE, 7, e43087. http://dx.doi.org/10.1371/journal.pone.0043087

[20] Kra, O., N’Dri, N., Ehui, E., Ouattara, B. and Bissagnene, E. (2007) Prévalence de l'antigène HBs chez les donneurs de sang au centre régional de transfusion sanguine de Bouake (Côte d’ivoire) en 2001. Bulletin de la Société de pathologie exotique, 100, 127-129.

[21] Sombié, R., Bougouma, A., Diallo, O., Bonkoungou, G., Cissé, R., Sangare, L., et al. (2010) Hépatite B chronique: Aspects épidémiologique, diagnostique, thérapeutique et évolutif au centre hospitalier universitaire Yalgado Ouédraogo de Ouagadougou. Journal Africain d'Hépato-Gastroentérologie, 4, 3-10. http://dx.doi.org/10.1007/s12157-009-0137-2

[22] Kodjo, N., Latoundji, S.B.I., Kposso, A.R., Saké, A.K., Vignon, R.K., Houinato, D., et al. (2014) Connaissances et croyances en matière d'hépatite virale B et C en république du Benin. Journal Africain d'Hépato-Gastroentérologie, 9, 2-6.

[23] Creach, M.-A. (2009) Aspects épidémiologiques et cliniques du portage chronique de l’antigène HBs dans les unités militaires des régions Nord-Est de la France. Thèse, Universtié de Nancy, Nancy, 82 p.

[24] Hadziyannis, S.J. (2011) Natural History of Chronic Hepatitis B in Euro-Mediterranean and African Countries. Journal of Hepatology, 55, 183-191. http://dx.doi.org/10.1016/j.jhep.2010.12.030

[25] Mulders, M.N., Venard, V.N., Jayou, M., et al. (2004) Low Genetic Diversity despite Hyperendemicity of Hepatitis B Virus Genotype E throughout West Africa. The Journal of Infectious Diseases, 190, 400-408. http://dx.doi.org/10.1086/421502

[26] Brunetto, M.R. (2010) A New Role for an Old Marker, HBsAg. Journal of Hepatology, 52, 475-477. http://dx.doi.org/10.1016/j.jhep.2009.12.020

[27] Hadziyannis, S.J. and Papatheodoridis, G.V. (2006) Hepatitis B e Antigen-Negative Chronic Hepatitis B: Natural History and Treatment. Seminars in Liver Disease, 26, 130-141. http://dx.doi.org/10.1055/s-2006-939751

[28] Ganji, A., Esmaeilzadeh, A., Ghafarzadegan, K., Helalat, H., Rafatpanah, H. and Mokhtarifar, A. (2011) Correlation between HBsAg Quantitative Assay Results and HBV DNA Levels in Chronic HBV. Hepatitis Monthly, 11, 342-345.

[29] Thompson, A.J., Nguyen, T., Iser, D., Ayres, A., Jackson, K., Littlejohn, M., et al. (2010) Serum Hepatitis B Surface Antigen and Hepatitis B e Antigen Titers: Disease Phase Influences Correlation with Viral Load and Intrahepatic Hepatitis B Virus Markers. Hepatology, 51, 1933-1944. http://dx.doi.org/10.1002/hep.23571

[30] Iloeje, U.H., Yang, H.I., Jen, C.L., Su, J., Wang, L.Y., You, S.L., et al. (2007) Risk and Predictors of Mortality Associated with Chronic Hepatitis B Infection. Clinical Gastroenterology and Hepatology, 5, 921-931. http://dx.doi.org/10.1016/j.cgh.2007.06.015

[31] Jang, J.W., Yoo, S.H., Kwon, J.H., You, C.R., Lee, S., Lee, J.H., et al. (2011) Serum Hepatitis B Surface Antigen Levels in the Natural History of Chronic Hepatitis B Infection. Alimentary Pharmacology \& Therapeutics, 34, 1337-1346. http://dx.doi.org/10.1111/j.1365-2036.2011.04888.x 